\title{
PROCESSES AND MODELS OF ANTARCTIC GLACIOMARINE SEDIMENTATION
}

\author{
by \\ D. J. Drewry and A. P. R. Cooper \\ (Scott Polar Research Institute, University of Cambridge, Cambridge CB2 1ER, England)
}

\section{ABSTRACT}

Glaciomarine sediments (GMS) comprise detrital, biogenic, and authigenic materials of two principal facies: laminated deposits and massive aqueous till. The processes governing sedimentation of the ice-rafted debris (IRD) component of GMS are investigated in the marine zone around Antarctica. Four controlling factors are identified: nature and disposition of sediments at the grounding line, transition from grounded to floating ice (ice shelves, outlet glaciers, and ice cliffs), processes of under-side melting and freezing of these ice masses, and, finally, mechanisms of iceberg calving, fragmentation, and melt-release of debris in the open ocean. Modelling studies of Brunt and Ross ice shelves suggest two main conclusions. (1) Ice shelves are of major importance for sedimentation on the continental shelf. Bulk debris release occurs within the grounding- 7 ine zone which may frequently oscillate, producing pronounced diachronism. Bottom melting removes al] debris prior to calving at the ice front so that ice shelves do not play a part in deposition in the open ocean. (2) Outlet glaciers, in contrast, have high sediment content, calve rapidly, and produce debris-rich icebergs which contribute the major portion of IRD in the ocean.

\section{INTRODUCTION}

Glaciomarine sediments (GMS), melted out and reworked from floating ice, comprise crudely sorted terrigenous sediments possessing an abundant silt-size fraction with scattered cobbles and associated alteration products, but poor in $\mathrm{CaCO}_{3}$ and other organic matter. Current hypotheses of glaciomarine sedimentation (e.g. Carey and Ahmed 1961) are based upon sketchy a priori assumptions and often upon outdated concepts. This study presents ideas for the interpretation of ice-rafted debris (IRD), based upon glaciological and oceanographic models. The marine zone around Antarctica is taken as a type area for discussion.

Four factors may be identified which control IRD (summarized in Figure 1): (1) nature of sediments in ice arriving in the marine environment; (2) nature of the transition from grounded to floating ice; (3) processes which operate at the ice/water interface of ice tongues and ice shelves, governing the amount of melt, if any, and, hence, the release of debris; (4) within the open ocean, IRD sedimentation is contralled by drift trajectories, me1t, and break-up history of those icebergs which contain debris.

NATURE OF SEDIMENTS ARRIVING AT GROUNDING LINE Glacial sediments destined for deposition in the ocean are incorporated into grounded ice masses at their surfaces, but more importantly by entrainment at the bed (Fig. 1). Basal debris-rich layers extend upwards from a few centimetres to several tens of metres. Typical values for margins of polar ice sheets appear to place the thickness of the debris layer at $-7 \%$ ice depth.

A basal debris layer may comprise several discrete bands of sediment-rich ice and the average concentration is extremely variable, from a fine dispersion ( $0.01 \%$ by volume) to upwards of 60 to $70 \%$. For an average polar ice sheet, the value is probably $-1 \%$. Observations of ice cliffs and cores indicate that there is usually a thick basal horizon of similar sediment content above which concentration shows a marked exponential decrease. Yevteyev (1959) has presented a detailed study showing this variation from ice cliffs near Mirny (Fig. 2). In order to model melt-induced debris release in later sections, we have represented the vertical variation in debris concentration by a Heaviside function of the form:

$C y / c_{0}=U_{0}(0)-U_{0}\left(y_{1}\right)\left(1-\exp ^{-k_{1}\left(y-k_{2}\right)}\right)$,

where $C$ is concentration at any height $(y)$ above bed, $C_{0}$ is initial concentration of basal layer, $K_{1}$ is constant, and $K_{2}$ is constant proportional to thickness of basal layer of constant debris concentration. $U_{0}(0)$ and $U_{0}\left(y_{1}\right)$ are Heaviside unit step functions. Equation 1 is depicted in Figure 2. The nature of the debris concentration function (DCF) at the grounding line is an extremely important factor in determining subsequent sedimentation rate beneath a floating ice mass. If, for instance, the melt rate and ice velocity were constant, sedimentation rate would directly mimic the DCF. Too few measurements of basal debris are available to suggest how typical Equation I may be.

\section{GROUNDING-LINE TRANSITION}

Excluding lodgement and melt-out of clastic materials benea th the grounded ice sheet, debris and ice are transferred out of the icesheet system in three modes. 


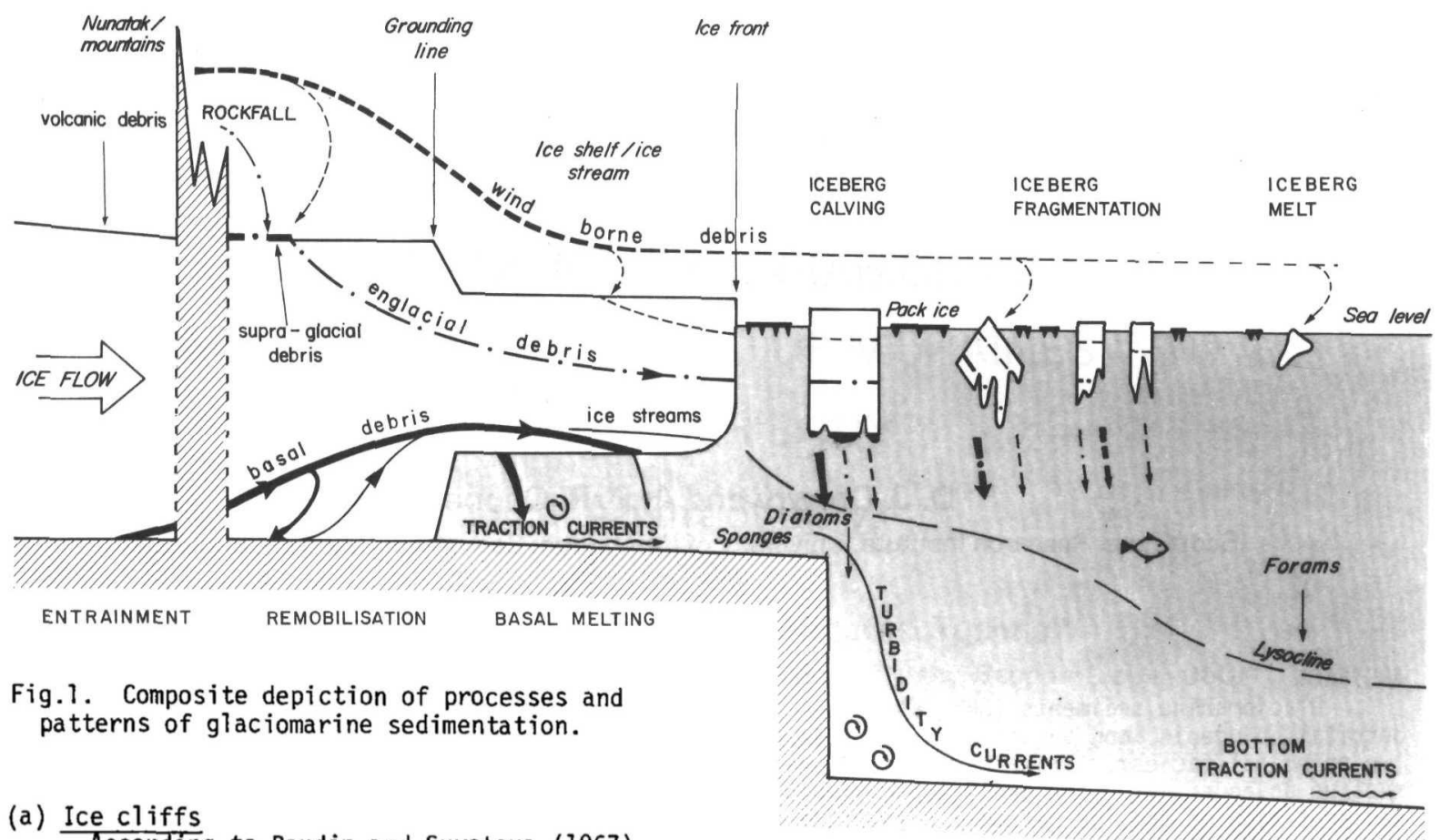

(a) Ice cliffs

According to Bardin and Suyetova (1967), ice cliffs account for $-16 \%$ annual ice discharge into the seas surrounding Antarctica.

Mass loss is small $\left(0.017 \mathrm{~km}^{3} \mathrm{~km}^{-1} \mathrm{a}^{-1}\right)$ and occurs principally by ice fall from unstable advancing ice cliffs. Wave action at the foot of ice cliffs and submergence of bottom sections of the ice front, and their slow rate of advance ( 5 to $50 \mathrm{~m} \mathrm{a}^{-1}$ ) when compared to outlet glaciers and ice shelves, promote bulk sedimentation close to the ice edge prior to calving.

\section{(b) Outlet glaciers and ice streams}

Intand ice draining towards the coast may become channelled into ice streams or outlet glaciers, the latter constrained by rock walls. Bardin and Suyetova (1967) indicate that discharge per unit width is high $\left(0.091 \mathrm{~km}^{3} \mathrm{~km}^{-1} \mathrm{a}^{-1}\right)$ and total annual discharge accounts for $22 \%$ of Antarctic mass loss into the sea.

observations of icebergs caiving from the front of outlet glaciers, including those that pass through a mountain belt, show that they retain basal debris (up to $15 \mathrm{~m}$ thick) plus a variable thickness of near-surface and recently
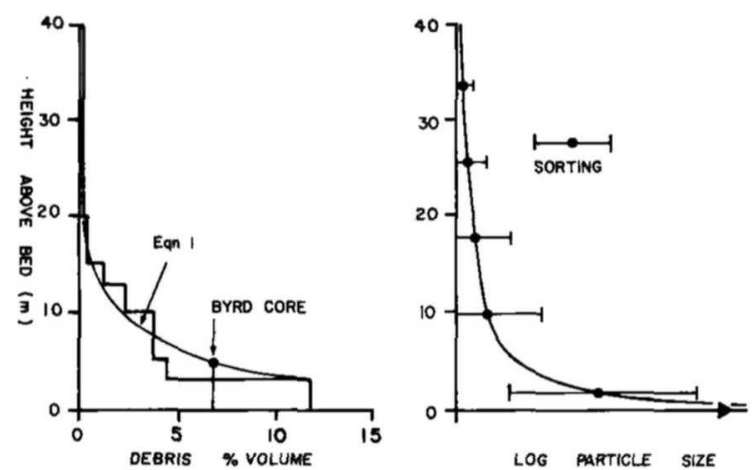

Fig.2. Debris characteristics for basal ice. Left: debris-concentration resuits of Yevteyev (1959) for ice cliffs near Mirny. Equation 1 is shown $\left[C_{0}=0.12 ; k_{1}=0.1\right.$; $\left.k_{2}=8 \mathrm{~m}\right]$. Spot value for basal debris in Byrd core is also shown. Right: an inferred depth-particle-size curve for a typical basal section of Antarctic ice. acquired moraine (Fig.1) (Bellair and others 1964, Anderson and others 1980). The release of sediments by melting beneath outlet glacier tongues is similar to that under ice shelves. As there is an almost continuous supply of small bergs with a high debris content (mean size $<1 \mathrm{~km}$ ) from outlet glaciers (compared to high-magnitude low-frequency calving of ice shelves), we suggest that the major portion of sediments discharged into the Southern Ocean comes from these outlet glaciers. Most icebergs calving from ice shelves are devoid of sediments.

\section{(c) Ice shelves}

Grounded ice may decouple upon entering deep water and float out over the sea where it experiences creep thinning from acceleration due to reduction of lateral and basal drag (Fig.1). Bardin and Suyetova (1967) indicate that ice shelf termini constitute the greatest discharge element for Antarctica at $62 \%$.

Important for sedimentation considerations are mass balance and particle paths. Ice shelves receive considerable surface snow accumulation. As rates increase towards the ice front, particle paths are inclined downwards at progressively steeper angles. If there is net basal melt, particle paths will intersect the bottom and any debris in transit in basal layers is likely to be rapidly melted out prior to calving at the ice-front (Fig.l), making ice shelves important for sedimentation at the inner margins of the continental shelf but of minimal significance to open-ocean glaciomarine sedimentation.

MODELLING BASAL MELT AND SEDIMENTATION FROM ICE SHELVES AND OUTLET GLACIERS Melting theory

When ice decouples from bedrock at the grounding line two possible regimes may develop at the ice/water interface. These are basal melting or freezing, and are governed by the upward heat fluxes from the sea $\left(Q_{s}\right)$ and through the ice $\left(Q_{i}\right)$ (Doake 1976):

$$
M=\left(Q_{\mathbf{S}}-Q_{\mathbf{j}}\right) / \rho_{\mathbf{i}} L
$$


where $M$ is melt rate (negative for freezing), $L$ is latent heat of fusion of ice, $\rho_{i}$ is density of ice.

$Q_{S}$ is a function of temperature above freezing, flow characteristics, and thermohaline convection, if it occurs. $Q j$ is the product of temperature gradient in the ice and thermal conductivity. As few data are available on the oceanographic regime beneath floating ice masses, indirect methods are required to estimate basal melting and freezing. Crary and others (1962) have given the following relationship based upon the assumption of steady state:

$$
M=-v(\mathrm{~d} H / \mathrm{d} x)+A+H \varepsilon_{z},
$$

where $v$ is horizontal velocity, $\mathrm{d} H / \mathrm{d} x$ is icethickness gradient along flow-line ( $x$ direction), $A$ is surface accumulation rate, and $\varepsilon_{z}$ is vertical strain rate $=-\left(\varepsilon_{x}+\varepsilon_{y}\right)$. Figure 3 shows computed melt rates from Equation 3 along flow lines for the Brunt and Ross ice shelves. In general, on larger ice shelves, melt rates decrease up the flow line from the ice front where the effect of active water circulation is greatest for heat exchange. Further inland, as heat exchange is weakened and a layer of cold isothermal low-salinity water develops, a zone of net basal freezing may be encountered, and enhanced where the ice base slopes strongly upwards (Robin 1979). Towards the grounding line, however, basal melting may again occur resulting from convective turbulent flow associated with tidal pumping and general circulation. Some investigators, however, suggest basal freezing may continue to the grounding line (Thomas 1976, Zotikov and others 1980). The amount of basal melt or on-freezing in any small horizontal element $(\mathrm{d} x)$ along a flow Tine is:

$$
\mathrm{d} y=(M \mathrm{~d} x) / v,
$$

where $M$ is melt/freeze rate, and $v$ is horizontal ice velocity. The quantity of sediment released at any point from the ice base will depend upon the vertical debris concentration function (Equation 1) and up-stream sedimentation melt history as given by integration of Equation 4. As $M$ and v vary along the flow line, Equations 1 and 4 have been solved numerically for two Antarctic ice shelves (Brunt and Ross). As the DCF is unknown, Equation 1 has been applied with variable thickness and volume concentration. The results are shown in Figure 3.

\section{Sedimentation}

It can be seen in Figure 3 that, due to the relatively thin basal debris zone, sedimentation is highly sensitive to melt rate. Strong melting elose to the grounding line, for instance, may remove all debris within the first few tens of kilometres of ice shelf. The effect of basal freezing prior to complete release of sediments is to shift the deposition curve further along the flow line. These findings are supported by two observations. First is the total absence of debris in core retrieved from the Ross Ice Shelf at $\mathrm{Jg}$ and the Amery Ice Shelf at Gl. At J9 $6 \mathrm{~m}$ of frozen-on sea ice were observed at the bottom of a $416 \mathrm{~m}$ core. Various estimates suggest an accretion rate of between 0.01 and $0.035 \mathrm{~m} \mathrm{a}^{-1}$ (Jacobs and others 1979 , Zotikov and others 1980). Morgan (1972) interprets the Amery core as comprising $270 \mathrm{~m}$ of glacier ice overlying $158 \mathrm{~m}$ of frozen-on sea ice with an inferred growth rate of 0.3 to $0.5 \mathrm{~m} \mathrm{a}^{-1}$. As the ice streams feeding both the $J 9$ and $\mathrm{Gl}$ sites are vigorous, possess beds at the pressure-melting point, and have velocities indicative of basal sliding, it is unlikely that bottom layers will be devoid of debris at the grounding line. It must be as sumed, therefore, that melt releasing sediments must take place further up-stream from the drill sites and close to the grounding line. Additional evidence for this explanation comes from the Maudheim Ice Shelf where Robin (1958) has reported that the seismic record from station 167, just beyand the grounding line, suggests the presence of a basal moraine layer ( $10 \mathrm{~m}$ thickness), while seismograms further out on the ice shelf show no such effect.

Secondly, geophysical studies in the grounding zone of both Ross and FilchnerRonne ice shelves suggest the presence of rapid$7 y$ accumulating sediments. Radio echo-sounding of the Filchner Ice Shelf indicates that its inner boundary rests upon soft unconsolidated water-saturated sediments over an area several tens of kilometres wide resulting from rapid melt-out of debris during initial stages of decoupling (Drewry and others 1980). Close to the grounding line of the Ross I ce Shelf, studies demonstrate only a thin and variable water column between ice shelf and unconsolidated strata with several regions of incipient grounding (Robertson and others, in press). Under steady-state conditions, therefore, we suggest that the bulk of basal debris is mel ted out close to the grounding line,

producing a zone of sediment progradation (Fig.4). There is a gradual facies change from coarse orthotills (Harland and others 1966) beneath melting ice streams to aqueous orthotills as ice becomes buoyant. Bottom traction currents generated by cold-water flow or from large-scale circulation may induce local scour and erosion. Preferential movement of finer fractions by this process results in gravel lags and production of residual paratills (Fig.4). Further from the grounding line the rate of sedimentation will drop rapidly with only finer material being deposited, due to the exponential nature of the DCF and particle-size distribution (Fig.2). With bottom-current transportation towards the open sea, paratills thus grade into a thin wedge of non-calcareous silts and clays with occasional dropstones.

Ice shelves and outlet glaciers are the most sensitive elements of large ice masses: they respond rapidly to sea-level and climatic changes. Frequent migration, therefore, over the continental shelf of the grounding line zone will produce a thick, complex, and strongly diachronous sequence of glaciomarine sediments (Fig.4).

\section{ICEBERG SEOIMENTATION}

Icebergs are produced from ice shelves, outlet glaciers, and ice cliffs, with size diminishing in that order. They are extremely important for open-ocean IRD sedimentation (i.e. up to $1000 \mathrm{~km}$ from the Antarctic coast). The processes of debris release, however, are poorly understood but depend upon mechanisms of calving, subsequent fragmentation, location, and quantity of debris, drift, and melt histories (Fig.1).

\section{(1) Debris content of icebergs}

The debris content of bergs will depend on their calving source. Most ice shelves will not produce bergs containing significant amounts of basal debris (sediment content can be computed using Equations 1 and 4). Any debris present may consist of englacial sediment ribbons from ice flowing into the ice shelf through exposed 

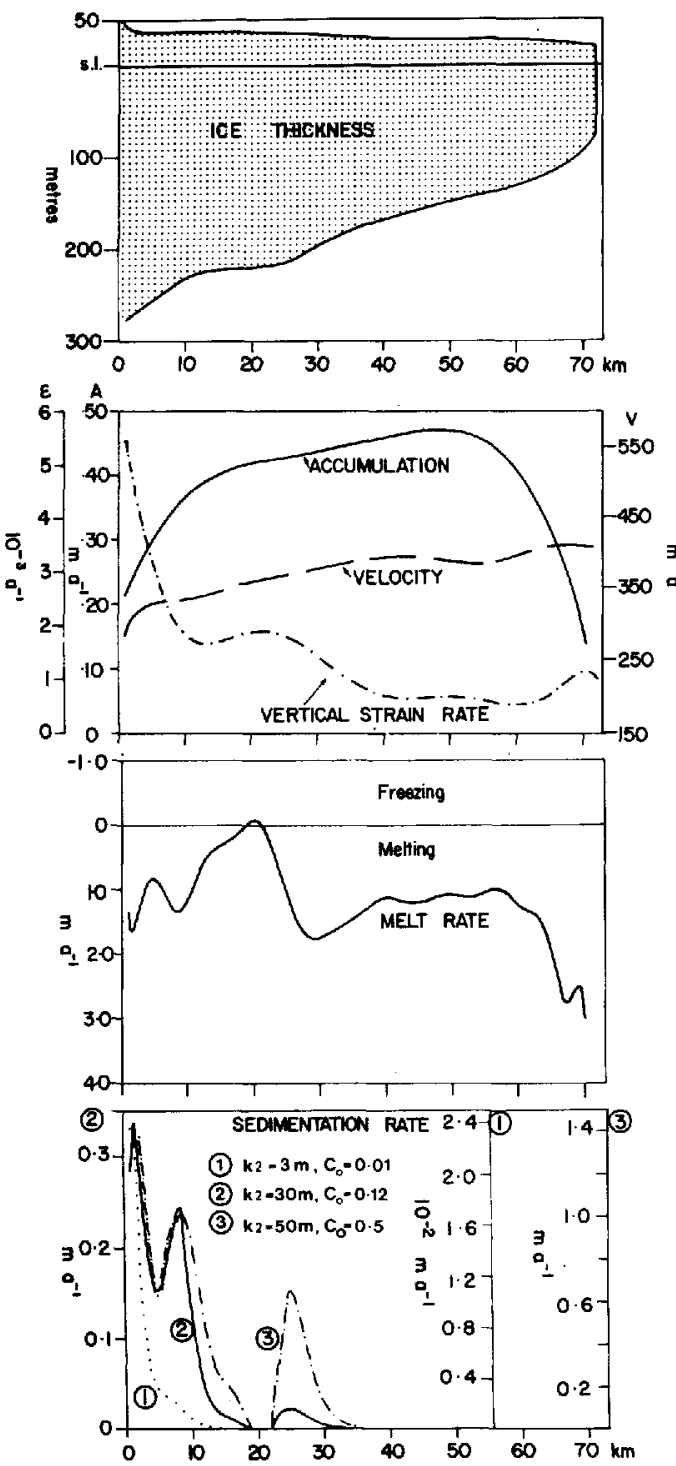
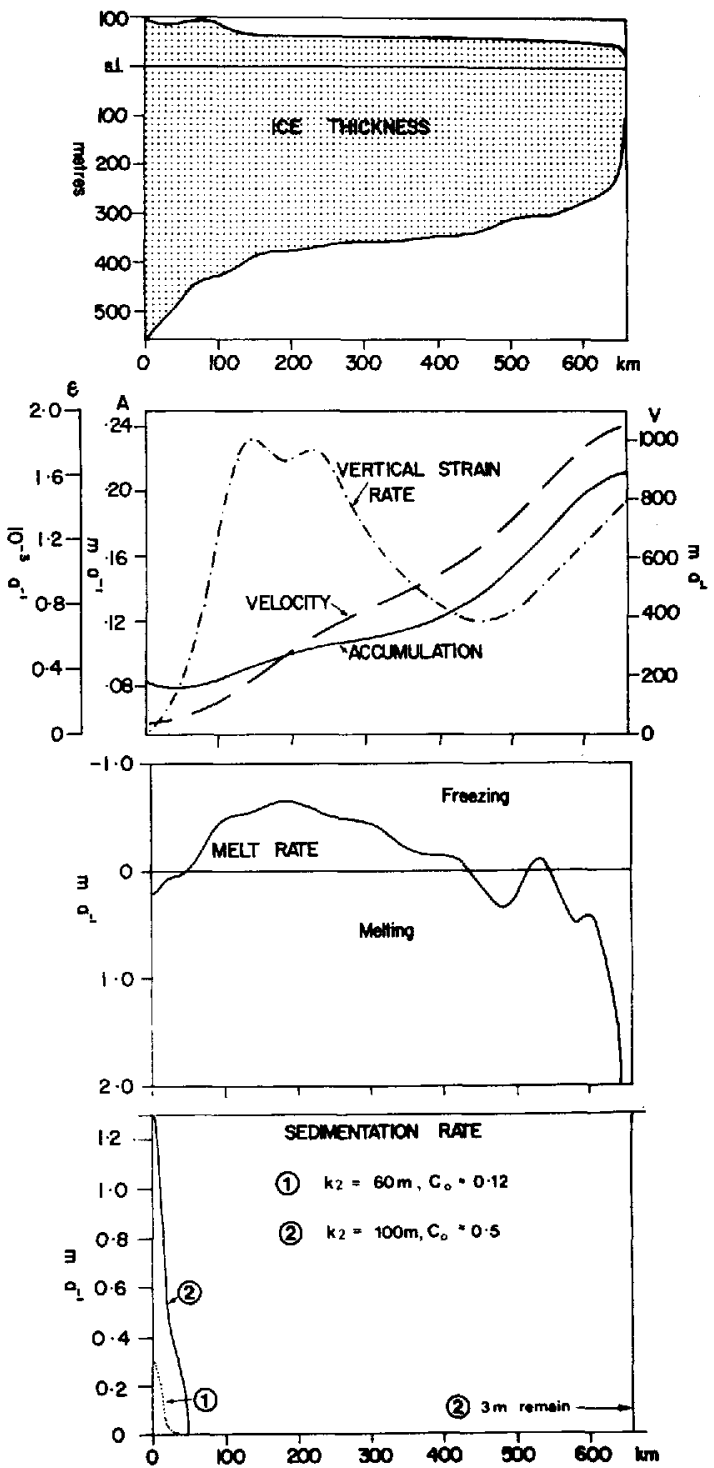

Fig. 3. Melt and sedimentation curves for Brunt (left) and Ross (right) ice shelves using Equations 1,3 , and 4 . Chebyshev polynomials have been fitted to all ice thickness, velocity, accumulation, and strain-rate raw data. Sources: ice-thickness data from SPRI radio echosounding, Brunt data from Thomas (1973), Ross data from Thomas (personal communication).

rock terrain. This may be the cause of banded icebergs observed off the Antarctic Peninsula. In the case of small ice shelves or those whose basal regime exceptionally favours extensive zones of bottom freezing, it is possible for limited amounts of basal debris to be present. outzet glaciers, however, appear to be the Jominant source of debris-rich icebergs due to their thick basal moraine layers, short length of floating section, and rapid calving.

\section{(2) Iceberg trajectories and velocities}

Typically, the drift of icebergs will depend upon predominant winds and currents, oceanic fronts, pack ice conditions, and

seabed topography. Until the advent of satellite surveillance it was difficult to track iceberg movements continuously with ease, and reliability. Even today few thorough studies have been undertaken to provide drift characteristics (e.g. Vinje 1980).

Tchernia and Jeannin (1980) tracked several icebergs around the coast of east Antarctica by means of transponders which were attached to the bergs and which relayed to Eole and Mimbus $F$ satellites. Average speeds recorded over periods of several hundred days ranged between 0.11 and $0.20 \mathrm{~m} \mathrm{~s}^{-1}$. Tchernia (1974) reports that such drift is between 60 and $75 \%$ of the ocean current velocity. The icebergs in question ranged in size from 0.4 to $3.8 \mathrm{~km}$ (length) with freeboards of 30 to $50 \mathrm{~m}$. Parts of the trajectories of several bergs showed a pronounced but irregular east-west movement close to the Antarctic coast line (100 to $150 \mathrm{~km})$ in the zone dominated by the East Wind Drift. Four icebergs showed distinctive recurvature of their

trajectories as they moved progressively further from the coast. Such motion indicates transition from the influence of westward flow close to the continental slope to the West Wind Drift, the primary circulation pattern of the Southern ocean.

This twofold distinction of drift tracks is important for distribution of sediments. Many icebergs tend to drift around Antarctica from east to west close inshore where waters are colder and constraining effects of thicker pack ice are greater and debris release consequently slower. Nevertheless, periods of several years spent in this zone (Vinje 1980) probably result 


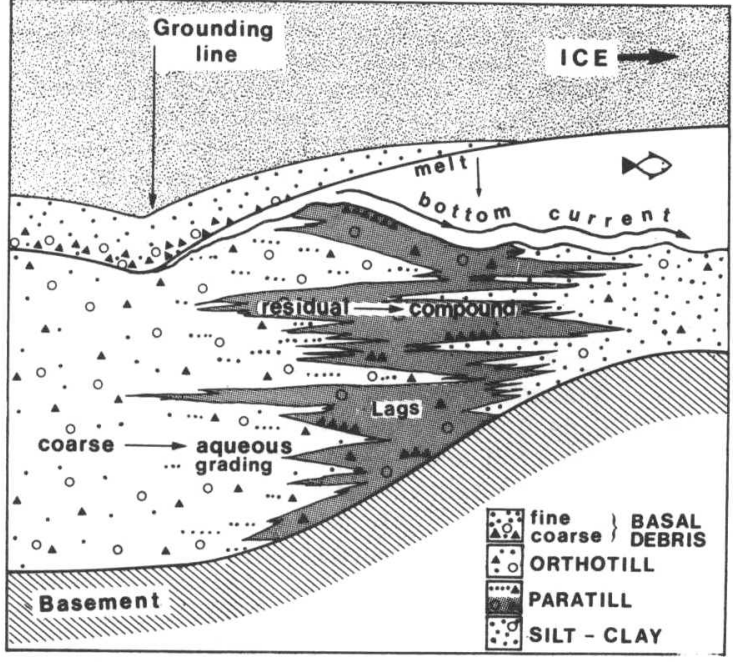

Fig.4. Sedimentary facies generated by floating ice shelf or outlet glacier exhibiting nonsteady state behaviour (irregular oscillation of grounding line) but no major erosive events are shown. See text for discussion.

in most basal debris being released on the continental shelf, generating an extremely coarse inner girdle of IRD. Bergs pushed towards the edge of the pack come under the influence of west-east currents and local gyres. Icebergs may then be swept both east and north into warmer waters where their melt rates are enhanced.

\section{(2) Debris release mechanisms}

\section{(a) Melt above the water ine}

Debris cropping out on the surface or sides of an iceberg is released by incoming solar radiation, giving rise to periodic debris falls, especially of coarse material, or a continuous rain of finer sediments. Close to the Antarctic coast, such release will be small due to low atmospheric temperatures and positive mass balances (the latter being reported for bergs south of $66^{\circ} \mathrm{S}$ in the Weddell Sea (Orheim 1980)). Nevertheless, the significantly reduced albedo of dirty ice may assist preferential melt-out during summer periods.

(b) Melt at and below the water line

Wave action gives rise to both water-line melting and collapse of undercut cliffs but, unless substantial amounts of debris are exposed at these locations, the sedimentational significance is not great. Melting of submerged side walls will also release debris and Huppert (1980) has calculated that rates of melt are in the order of $\mathrm{m} \mathrm{a}^{-1}$.

A] though overturned icebergs may possess debris in almost any place, it is most likely for sediments to reside in the base. Bottom melting of icebergs is similar to that of floating ice attached to land, except that drift velocity, the effects of currents, and other oceanic factors are more pronounced. In general, melt rates are lower than those for side walls (Huppert 1980). Several studies have suggested rates of bottom melting varying between 0.1 and $100 \mathrm{~m} \mathrm{a}^{-1}$. Martin and Kauffman (Huppert 1980) give extrapolated bottom melt rates in the order of 0.5 to $1 \mathrm{~m} \mathrm{a-1,} \mathrm{similar} \mathrm{to} \mathrm{theoretical} \mathrm{sugg-}$ estions by both Gade (1979) and Weeks and Campbe11 (1973). Budd and others (1980), however, report average, all-round ice loss (i.e. buttom and sides) two orders of magnitude greater, obtained from consideration of the steady-state flux of icebergs in the Southern Ocean. These values are similar to those obtained in laboratory experiments by Russe17-Head (1980). We have calculated melt rates for given water temperatures using: (i) Weeks and Campbell's method, (ii) Russell-Head's experimental relationship, and ( $i i j$ ) the Budd and others (1980) envelope. Resuits are given in Table I. If icebergs are held close into the Antarctic coast for up to five years (Vinje 1980), all basal debris would be released prior to drift into the open ocean. Only fragmentation and overturning would preserve material in the iceberg for rafting at great distances from the coast. It is not certain, however, whether basal debris layers inhibit or enhance bottom melting. Laboratory experiments should be undertaken to evaluate factors important in heat transfer through a sediment-charged basal horizon.

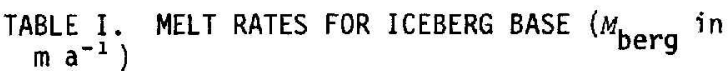

$\begin{array}{lccc}\begin{array}{l}\Delta T \\ { }^{\circ} \mathrm{C}\end{array} & \begin{array}{c}\text { Weeks and } \\ \text { Campbel1 * }\end{array} & \begin{array}{c}\text { Russell- } \\ \text { Head* }\end{array} & \begin{array}{c}\text { Budd and } \\ \text { otherst }\end{array} \\ 0.5 & 0.07 & 23 & 15-55 \\ 1.0 & 0.15 & 31 & 18-70 \\ 2.0 & 0.30 & 49 & 33-80 \\ 5.0 & 0.74 & 117 & 37-95\end{array}$

$x M_{\text {berg }}=\left(L V_{b}{ }^{0.8} \Delta T\right) / x_{b}{ }^{0.2}$

where $L$ is constant, $V b$ is relative free stream flow velocity $\left(=0.05 \mathrm{~m} \mathrm{~s}^{-1}\right)$, and $x_{0}$ is iceberg length $(=1 \mathrm{~km}) . \Delta T$ is ice/water temperature difference.

${ }^{{ }^{\prime}}{ }_{\text {berg }}=1.8 \times 10^{-2}(\Delta \mathrm{T}+1.8)^{1.5}$

tFrom Budd and others (1980, figure 15).

(c) Dramping

During fragmentation, tilting and overturning of icebergs, any loose sediments may simply be dumped into open water giving rise to periodic sedimentation events. In addition, upturned bergs containing debris may concentrate sediment at their upper surfaces by melting from solar radiation. Periodic saturated flow or slumping of such debris may release material over the sides of a berg (Ovenshine 1970). Meltwater rivulets also carry away fines in suspension, or larger particles in traction.

Figure 5 illustrates a hypothetical debrisrelease history for an outlet glacier berg. Dumping, mudflow, dirty melt-water contributions, and basal and radiation melt episodes give rise to highly irregular and complex patterns of

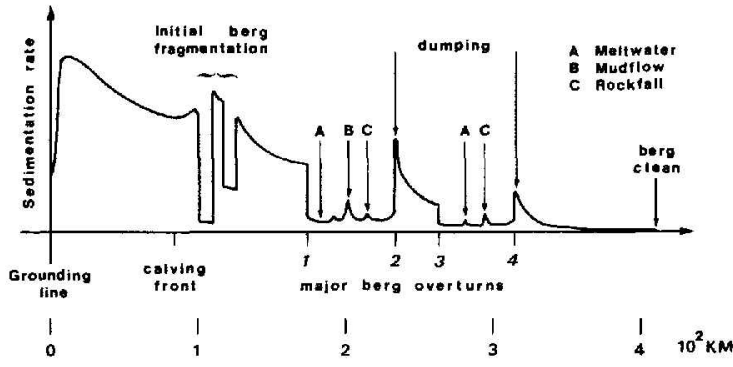

Fig.5. Hypothetical debris-release history for icebergs calving from ice stream/outlet glaciers. 
sedimentation, such as sporadic patches of coarse or mixed deposits lying upon and often interbedded with finer silty sediments. Nevertheless, there is a steady decline in rate of deposition as the berg is progressively cleaned of debris. Several of these events are shown in Figure 5.

\section{ACKNOWLEDGEMENTS}

Radio echo-sounding data used in this study were gathered in a programe funded by the U.K. NERC Grant GR3/2291 and with the generous logistic support of the U.S. National Science Foundation. We thank Dr C.S. Neal for helpful discussions, S. Jordan for assistance with diagrams, and Dr R.H. Thomas for providing unpublished data for the Ross Ice Shelf.

\section{REFERENCES}

Anderson J B, Domack E W, Kurtz D D 1980 abservations of sediment-laden icebergs in Antarctic waters; implications to glacial erosion and transport. Joumaz of Glaciology 25(93): 387-396

Bardin V I, Suyetova I A 1967 Basic morphometric characteristics for Antarctica and budget of the Antarctic ice cover. In Nagata $T$ (ed) Proceedings of the symposium on Pacific-Antaretic sciences. Tokyo, Dept of Polar Research, National Science Museum: Sci. Rpts. 92-100 (Japanese Antarctic Research Expedition Scientific Reports. Special Issue 1)

Bellair P, Tourenq $J$, Vernhet S 1964 Un échantillon de moraine interne du Glacier de 1 'Astrolabe (Terre Adelie). Revue de Géographie Physique et de Géologie Dynamique Sér 2 6(2): 115-121

Budd W F, Jacka T H, Morgan V I 1980 Antarctic iceberg melt rates derived from size distributions and movement rates. Annals of Glaciology 1: 103-112

Carey S W, Anmed N 1961 Glacial marine sedimentation. In Raasch G O (ed) Geology of the Arctic. Toronto, University of Toronto Press: 865-894

Crary A P, Robinson E S, Bennett H F, Boyd W W, Ir 1962 Glaciological studies of the Ross Ice Shelf, Antarctica, 1957-60. IGY GLaciological Report 6

Doake C S M 1976 Thermodynamics of the interaction between ice shelves and the sea. Polar Record 18(112): 37-41

Drewry D J, Meldrum D T, Jankowski E 1980 Radio echo and magnetic sounding of the Antarctic ice sheet, 1978-79. Polar Record 20(124): 43-51

Gade H G 1979 Melting of ice in sea water: a primitive model with application to the Antarctic ice shelf and icebergs. Joumal of Physical Oceanography 9(1): 189-198

Harland W B, Herod K N, Krinsley D H 1966 The definition and identification of tills and tillites. Earth-Science Reviews 2: 225-256

Huppert HE 1980 The physical processes involved in the melting of icebergs. Annals of Glaciology 1: 97-101

Jacobs S S, Gordon A L, Ardai J L, Jr 1979 Circulation and melting beneath the Ross Ice Shelf. Science 203(4379): 439-443

Morgan V I 1972 Oxygen isotope evidence for bottom freezing on the Amery Ice Shelf. Nature 238(5364): 393-394

Orheim 01980 Physical characteristics and life expectancy of tabular Antarctic icebergs. Annals of Glaciology 1: 11-18
Ovenshine A T 1970 Observations of iceberg rafting in Glacier Bay, Alaska, and the identification of ancient ice-rafted deposits. Geological Society of America Buzletin 81(3): 891-894

Robertson $J \mathrm{D}$, Bentley $C R, C l$ ough $J W$, Greischar $L L$ In press. Sea bottom topography and crustal structure below the Ross Ice Shelf. Antarctica. In Craddock C (ed) Antarctic geoscience. Proceedings of the third Symposizm on Antarctic Geology and Geophysics, Madison, 1977. Madison, WI, University of Wisconsin Press

Robin G de Q 1958 Glaciology. III. Seismic shooting and related investigations. Norwegian-British-Swedish Antarctic Expedition, 1949-52. Scientific Reports 5

Robin G de $Q 1979$ Formation, flow, and disintegration of ice shelves. Journal of Glaciology 24(90): 259-271

Russe11-Head D S 1980 The melting of freedrifting icebergs. Annals of Glaciologys $1: 119-122$

Tchernia P 1974 Étude de la dérive antarctique Est-Ouest au moyen d'icebergs suivis par le satellite Éole. Comptes Rendus Hebdomadaires des Séances de l'Académie des Sciences (Paris) Ser D 278(14): 667-670

Tchernia $P$, Jeannin P F 1980 Observations on the Antarctic East Wind Drift using tabular jcebergs tracked by satellite Nimbus F (1975-77). Deep-Sea Research 27A(6): $467-474$

Thomas R H 1973 The dynamics of the Brunt Ice Shelf, Coats Land, Antarctica. British Antarctic Survey Scientific Reports 79

Thomas R H 1976 Thickening of the Ross Ice Shelf and equilibrium state of the west Antarctic ice sheet. Nature 259(5540): 180-183

Vinje TE 1980 Some satellite-tracked iceberg drifts in the Antarctic. Annals of Glaciology 1: 83-87

Weeks W F, Campbell W J 1973 Icebergs as a freshwater source: an appraisal. Journa of Glaciology 12(65): 207-233

Yevteyer S A 1959 Opredeleniye kolichestva morennogo materiala, perenosimogo lednikami vostochnogo poberezh'ya Antarktidy [Determination of the amount of morainic material carried down by glaciers of the east Antarctic coast]. Informatsionnyy Byulieten' Sovetskoy Antarkticheskoy Ekspeditsii 11: 14-16

Zotikov I A, Zagorodnov V S, Raikovsky J V 1980 Core drilling through the Ross Ice Shelf (Antarctica) confirmed basal, freezing. Science 207(4438): 1463-1465 